811.163.41'367.625

811.163.41'373.611

https://doi.org/10.18485/sj.2020.25.1.19

МИЛИЦА Љ. СТОЈАНОВИТ ${ }^{*}$

Институт за српски језик САНУ

Београд
Оригинални научни рад

Примљен: 15. 10. 2019.

Прихваћен: 15. 01. 2020.

\title{
ГЛАГОЛИ СА ИНИЦИЈАЛНИМ МОРФЕМСКИМ СЕГМЕНТОМ ОБЕЗ- У СРПСКОМ ЈЕЗИКУ**
}

Истраживање глагола са почетним морфемским сегментом обез- (обезбојити, обезједрити, обезубити и сл.) има за циљ да се утврди начин творбе ових глагола - да ли је реч о префиксално-суфиксалној творби, творби сложеним префиксом или неком другом начину творбе. Следећи задатак рада је да се одреди шта је код ових глагола основински, а шта формантски део, те шта је њихова мотивна реч - именица или придев. У раду ћемо применити аналитичку, дескриптивну и творбену анализу, а лексикографске дефиниције ће нам послужити као творбене парафразе значења.

Кључне речи: глаголи са морфемским сегментом обез-, мотивна реч, вишеструка мотивација, проширени префикс.

1. Увод. У српском језику одређени број глагола почиње морфемским сегментом обез- и његовим аломорфима обес-, обеш- и обе-. Увид у досадашња испитивања овог иницијалног морфемског сегмента открива да у домаћој граматичкој литератури не постоји јединствен став о томе како овај сегмент треба посматрати у морфемској и творбеној структури глагола.

*Milica.Stojanovic@isj.sanu.ac.rs

** Овај рад је настао у оквиру пројекта 178009 Лингвистичка истраживања савременог српског књижевног језика и израда Речника српскохрватског књижевног и народног језика САНУ, који у целини финансира Министарство просвете, науке и технолошког развоја Републике Србије. 
Истраживање глагола са почетним морфемским сегментом обез- има за циљ да се утврде начини творбе ових глагола и да се установи могућност разграничења различитих творбених начина који се издвајају у литератури - да ли је то префиксација глагола префиксом o- или пак обез- чини сложени префикс или можемо говорити о нечему другом. Покушаћемо да утврдимо шта је код ових глагола основински, а шта формантски део, као и шта је њихова мотивна реч - именица или придев. У раду ћемо применити аналитичку, дескриптивну и творбену анализу, а лексикографске дефиниције ће нам послужити као творбене парафразе значења.

Основни извор грађе представља 16. том Речника САНУ у коме су обрађени глаголи са почетним сегментом обез-. Један број глагола ексцерпиран је из Речника ЈАЗУ. Као извор послужио нам је и интернет као и текстови различите природе ${ }^{1}$. Дакле, с обзиром на изворе, грађа истраживања, осим стандардне, обухвата и лексику која је временски, територијално и стилски маркирана.

2. ПрегЛЕД ЛИтерАтурЕ. У прегледу литературе најпре ћемо навести мишљења о томе ком типу творбе припадају ови глаголи, а затим и ставове о томе шта је у основи ових глагола.

2.1. У словенској лингвистичкој науци наилазимо на различита тумачења структуре овог морфемског сегмента. Показало се да творба глагола типа обезобразити се, обезглавити, обезвучати и сл. представља проблем за који се нуде разноврсна решења.

2.1.1. Према мишљењу Маретића (1931) и Белића (1949), глаголи типа обезобразити се, обезочити и сл. имају само један предметак: о-. И међу савременим ауторима има оних који овај начин творбе сврставају у префиксално-суфиксални и, такође, виде само један префикс, о- (Клајн 2002: 296; Ћихоњска 1987: 78; Бабић 2002: 556). Такво мишљење у русистици заступа Исаченко (1960: 150-151), који наводи да семантичка и творбена анализа глагола са елементом обез- упућује на префиксално-суфиксалну творбу, те се по творби руски глаголи о-безвред-ить или о-бессил-еть не разликују од глагола типа $о$-черн-ить или $о$-слаб-еть, где се као глаголски префикс јавља само префикс $o-$.

2.1.2. Према ауторима Хрватске граматике, ови глаголи су сложени са два префикса (ХГ 1997: 387). Такође и Драгићевић (2013: 262) глаголе типа обезмастити, обезвучити, обесолити посматра као двопрефиксалне глаголе. О дуплој префиксацији код глагола типа обешчовечити говори и Штасни (2013: 18).

${ }^{1}$ Пронађен је велики број примера, али због ограниченог обима рада, наводићемо само оне неопходне за илустрацију појаве коју описујемо. 
2.1.3. Према руској литератури, код ових глагола није реч о дуплој префиксацији, већ о сложеном префиксу обез- (в. Ројзензон 1966: 87; РГ 1980: 754). Да је то у неким случајевима сложени префикс, наводи и Бабић (2002: 557).

2.2. Друга неуједначеност у литератури у представљању глагола са сегментом обез- тиче се њихове основе, односно питања шта је у њиховој основи - именица, придев или нешто треће.

Маретић (1931: 350) сматра да су примери типа обезобразити, обезочи$m и$ и сл. начињени према „сложеним” придевима безобразан, безочан и сл. Мишљење да су овакви глаголи мотивисани именицом налазимо у РГ (1980), док Ћихоњска (1987: 78) издваја ову, по њеним речима, малу групу глагола, која је изведена од „предлошких конструкција с формалном структуром” оПК-ити. На један префикс и окамењени предлог, односно предлошко-падежну везу у глаголима обезглавити, обезубити, обешчастити, обештетити, обеспаметити указује и Маројевић (2005: 767).

Бабић и Клајн у својим монографским студијама о творби речи по питању мотивације ових глагола прилично су неодређени. Тако Бабић (2002: 556-557) наводи да ови глаголи могу бити изведени од придева (обезобразити, обезглавити, обесмртити и сл.), именица (обезглавити, обесмртити, обешчастити и сл.) или придева сложеним префиксом обез- (обесхрабрити, обезнанити се и сл.). Дакле, глаголе обезглавити и обесмртити наводи и као примере глагола изведених од придева и као примере глагола изведених од именица.

Клајн (2002: 296) сматра да су од придева на без- добијени глаголи обезглавити (<безглав), обезубити, обезб(иј)едити, обезвр(иј)едити, обесрамити, обезобразити (се), обесправити, вероватно и обешчастити и обеси(иј)енити, док су од префикса, основе (именичке, ређе придевске) и суфикса настали глаголи обештетити $(<0-+б е з-+$ итет $(a)+-$-ити), обезоружати, обеспокојити, обеснажити, обеспаметити, обесхрабрити и можда још покоји.

2.3. Осим узгредних помињања у граматикама и појединачним радовима, није нам познато да се у српској лингвистици неко шире бавио овим питањем. Због тога су одговори на наведена питања у домаћој литератури прилично уопштени, неуједначени и не наилазимо на коначно задовољавајуће решење. Што се тиче шире, словенске перспективе, овим проблемом у руском језику темељно се бавила О. Пацјукова у својој докторској дисертацији (Пацјукова 2014), као и у неколико радова (Пацјукова 2009; 2011; 2012). Њена анализа је комплетна и детаљна и чини се да су употребљена методологија, начин излагања и аргументовања погодни за испитивање оваквих глагола. У нашем истраживању применићемо сличан модел анализе и упоредити добијене резултате са резултатима до којих је она дошла.

Пацјукова у раду Протяжённый префикс обез-(обес-): формирование и функионирование (Пацјукова 2009) описује формирање и функционисање 
проширених афикса, посебно афикса обез-, као активни процес у творби речи. Она уместо термина сложени префикс користи термин проширени префикс (афикс). Ауторка (2009: 308) наводи да се проширени афикс етимолошки дели на две-три компоненте (две-три просте морфеме), које се у савременом језику појављују као једна морфема која у језику испуњава одређену семантичку и граматичку функцијуㄹ․ Таква њихова природа изазива значајне потешкоће у интерпретацији. По речима О. Пацјукове (2009: 308), формирање проширеног префикса обез- веома је дуг процес.

Користећи дијахронијски и синхронијски приступ, у развоју проширеног префикса Пацјукова наводи три етапе. Прву етапу карактерише постојање глагола без префикса о- (беспокоить, бесчестить).

Следећа етапа формирања проширеног префикса препознаје се код највећег броја глагола у руском језику. За ове глаголе карактеристичан је двоструки творбени однос. Они се могу извести од придева (о-безвод-е-ть $\leftarrow$ безводньій) или именице без префикса (обез-вод-е-ть Łвода) У овим глаголима префиксални елемент појављује се као спој две морфеме, морфемски комплекс, а затим и као потпуна проширена јединица.

За глаголе с морфемским комплексом карактеристичан је пун творбени ланац који се састоји из три карике: 1) именица, обично неизведена; 2) придев; 3) глагол.

Трећа етапа у творби ових глагола је она у којој спој префикса обезфункционише као потпуна проширена јединица (обезбомбеть $\leftarrow$ бомба, обезрусеть $\leftarrow$ русский).

3.1. МОРФЕМСКА И ТВОРБЕНА АНАЛИЗА ГЛАГОЛА СА СЕГМЕНТОМ ОБЕЗ- У СРпском ЈЕзику. У српском језику глаголи који на почетку имају сегмент обез- не могу се посматрати као глаголи са два префикса, јер без- није глаголски префикс. Имајући у виду ранију литературу и истраживања и неусклађеност у коришћењу термина и анализи грађе, одлучили смо се да у нашој анализи користимо неутрални термин „морфемски сегмент” зато што не можемо у свим случајевима говорити о формалном и семантичком јединству морфема $o$ - и без-. Термином „проширени префикс”, који користи Пацјукова, служићемо се само када је јасно да је обез- јединствен творбени формант са одређеном семантиком.

Као проширене афиксе који функционишу у руском језику, Пацјукова наводи још и суфиксе са почетним елементом -тель: -тельск/ий/, -тельн/ьй/, -тельниц/a/, -тельств/о/; са почетним елементом -ист: -истк/a/, -истик/a/, -истск/ий/, -истическ/ий/, -истичн/ьй/ и са почетним елементом -ник: -нича/ть/, -ничеств/о/, -ническ/ий/, -ничий/ø/. Међу проширене префиксе Пацјукова, осим обез-, убраја и небез- и недо- (Пацјукова 2014). 
У српском језику у структури морфемског сегмента обез- запажамо две компоненте: префикс $o$ - и префикс без-. Префикс $o$ - у глаголима има или граматичку функцију, служи за образовање глагола свршеног вида, или, у одређеним глаголима, његово значење је „придавање објекту особине исказане придевом (ако су прелазни), односно стицање такве особине (непрелазни)" (Клајн 2002: 261). У том случају овај префикс истовремено има и творбено и граматичко значење.

Префикс без- користи се у творби придева и именица и својом семантиком упућује на одсуство некога или нечега. Овај префикс по пореклу је предлог без који се користи са именицама у генитиву.

Према РЈАЗУ и РСАНУ, у српском језику постоји одређени број глагола који почињу морфемом без-: безаконовати безглавити се, безматичити (се), безобразити (се), безочити, безумити (се), безумствовати, безуфати се, бесветити, бесвијестити се, беславити, бесмртовати, беснажити, беспокојавати (се), беспокојити (се), беспосличарити, беспосличити, беспословати, бестрагавати, бестрагати, бесхлебовати, бесијењивати, бешчастити (се), бешчестити, бесправдовати, беструдновати, бестужсти се, бешчастовати, бездјелствовати, безредити, безређивати.

Већину ових глагола можемо срести у функционалностилски обележеним текстовима богословског садржаја ${ }^{4}$ (безаконовати, бешчастити, безумствовати, бесмртовати, беспокојити, бешчестити), док се веома ретко јављају у савременом књижевном или разговорном језику (беспокојити, бесветити, бешчастити). Неки глаголи су из дијалеката или разговорног језика прешли у стандардан речник (безобразити (се), беспосличарити, беспосличити ${ }^{5}$ ):

Преступник ће и даље преступати, а безаконик ће безаконовати (svetosavlje.org).

Свети пут богочовечанске вере јесте: „Са свима светима” саборно мислити, саборно осећати, $[. .$.$] саборно бесмртовати, и тако узрастати „у човека савршена [...]”$ (svetosavlje.org).

Свако нека штеди за своје здравље, а не да се они безобразе за наше паре (интернет).

Онај ко буде изабран добиће авионску карту до острва Хамилтон [...] где ће морати да станује наредних шест месеци, током којих ће се шетати и беспосличити (интернет).

${ }^{3}$ Подвучени глаголи немају одговарајући префиксирани дериват изведен префиксом $o$ -

${ }^{4}$ Према речима В. Јовановића (Јовановић 2020), „префикси без- и не- представљају специфичност творбеног система сакралног функционалностилског комплекса, будући да је продуктивност ових префикса у неутралном стилу српског језика знатно нижа, често ограничена на индивидуалну и стилски маркирану лексику”.

${ }^{5}$ Глаголе беспосличарити и беспосличити дијалекатски лексикографи често користе у својим синонимским дефиницијама: за беспосличарити в. Стијовић 2014, под луфтират; за беспосличити в. Гаговић 2004, под вегурати се; Ћупић Д. и Ж. 1997, под зврндат, и под ћутукат; Ђукановић 1995, под лињати; Стијовић 2014, под доколичит. 
Специјалној лексици из области пчеларства припада лексема безматичити (се).

Што се тиче творбе ових глагола, они су у највећем броју мотивисани предлошко-падежном конструкцијом, у њиховој мотивационој основи је именица, односно конструкција без + именица: безматичити - „убијати матицу, остављати без матице”, беспосличити - „бити без посла”, бесхлебовати - „бити без хлеба”, бешчастити „остављати без части”, бесвијестити се „губити свест” итд. Могу имати и двоструку мотивацију - могу бити изведени од придева или конструкције без + именица: безобразити се - „постајати без образа, постајати безобразан”, беснажити „чинити беснажним, чинити да неко остане без снаге”, бестужити се „бити бестужан/без туге”.

Када се оваквом глаголу, без обзира на начин његове творбе и порекло, дода префикс o-, он мења његов вид и уноси сему резултативности или каузативности (безглавити се -о-безглавити (се), безматичити - обезматичити). Наравно, нису сви глаголи подлегли префиксацији, али можемо приметити да су глаголи са префиксом $о$ - уобичајенији, чешћи у употреби, са више потврда и развијенијом полисемантичком структуром. Чак и у РЈАЗУ ови су глаголи испоређени са својим префиксираним парњацима (безобразити се, безматичити $\mathrm{ce}^{6}$ ) или се префиксирани глаголи јављају у синонимском делу дефиниције (в. под беснажити, беспокојити/обеспокојавати). Код неких префиксираних глагола током времена дошло је до померања значења. Тако, на пример, данашње значење глагола обезаконити „ставити ван закона, учинити безаконитим, противзаконитим" (Обезаконити производњу биокарбураната, (интернет)), не можемо семантички довести у блиску везу са некадашњим глаголом безаконити „чинити безакоње силујући женско”.

На основу грађе, можемо рећи да творбени тип глагола који на почетку имају морфему без- више није продуктиван и да се на овај начин данас не стварају нове глаголске јединице. Глаголи с префиксом $о$ - изведени од наведених глагола (обезобразити, обезматичити и сл.) представљају почетну фазу у формирању проширеног афикса и ова фаза представљена је и у савременом српском језику малим бројем примера. Иста ситуација је и у руском језику (в. Пацјукова 2014).

3. 2. За другу групу глагола карактеристично је да се формално и семантички могу довести у везу са две лексеме. Они се могу извести од придева (безглав $\rightarrow$ о-безглав-и-ти) или именице (глава $\rightarrow$ обез-глав-и-ти), али могу бити мотивисани и предлошко-падежном конструкцијом без + именица (о-без-глав-ити). У овој групи глагола с једне стране чувају се старе системске везе и префиксални елемент се појављује као спој две морфеме, а са друге (РJA3У).

${ }^{6}$ „Остајати без матице, постајати безматак, у наше вријеме испореди обезматичити се” 
развијају се нове и појављује се сегмент обез- као самостална јединица. За ову групу глагола најважније је истаћи постојање трокомпонентног ланца који чине именица, придев и глагол:

зуб - безуб - обезубити („остати без зуба, изгубити зубе”)

вољ $а-$ безвољан - обезвољити (,учинити безвољним, лишити воље за нечим”)

боја - безбојан - обезбојити (,учинити безбојним, лишити боје”)

брига - безбрижсан - обезбрижити (,лишити брига, учинити безбрижним”)

звук - безвучан - обезвучити (,изгубити звучност, постати безвучан”)

оружје - безоружан - обезоружати („одузети некоме оружје, оставити некога без оружја")

сан - бесан - обесанити се (,изгубити сан, постати бесан”)

снага - беснажан - обеснажити (,лишити снаге”)

крило - бескрилан - обескрилити (,остати без крила”)

глава - безглав - обезглавити („одсећи, одрубити некоме главу, оставити без главе")

хлеб - бесхлебан - обесхлебити („учинити да неко остане без хлеба, без основних средстава за живот")

душа - бездушан - обездушити (,лишити (некога или нешто) душе”)

круна - бескрун - обескрунити (,„ишити круне, престола, власти”)

кућа - бескућан - обескућити (,,лишити куће”)

вредност - безвредан - обезвредити (,учинити безвредним, лишити вредности”)

Троструку мотивацију ових глагола најчешће потврђују и њихове лексикографске дефиниције. Мотивациону основу може чинити придев ${ }^{7}$ или именица, односно предлошко-падежна конструкција коју чини предлог без и именица. Префикс $о$ - у овим глаголима има семантику „учинити/постати каквим" и истовремено изражава значење свршеног вида. Творбена функција префикса $o$ - у датом случају је мутациона, јер је у вези с образовањем нове речи друге врсте. Према речима Пацјукове (2009: 311), префикс без- губи деривациону функцију, постаје део творбене основе, а резултат тога је да му значење слаби, а семантичко оптерећење се премешта на глаголски префикс. На тај начин се информативно оптерећење морфема прераспоређује, семантички оптерећене тачке постају корен и други префикс који међусобно утичу један на други, и то води појави друге мотивације глагола с морфемским комплексом обез-, дакле мотивациона основа није само придев с префиксом без-, већ и сама именица. Формирање семантике новог афикса Пацјукова (2009: 311) изражава на следећи начин: „учинити/постати каквим” $\rightarrow$,учинити/постати лишеним/ лишен нечега” $\rightarrow$ „лишити (се) нечега”. Путем семантичке апсорпције долази

${ }^{7}$ Глагол обесмртити има само придев у мотивационој основи, на шта указује и његова лексикографска интерпретација „учинити бесмртним”. Сматрамо да је овај глагол мотивисан придевом зато што га не можемо дефинисати као „лишити смрти”.

Такође и глагол обезочити (ce) „постати безочан, безобзиран” сматрамо изведеним од придева безочан, као и обезбедити од безбедан, али ови придеви су са синхроног становишта неизведени, тако да они ни не улазе у наш корпус. Овде не убрајамо придев безобразан „бестидан, бесраман, бешчастан”, јер именица образ чува значење „част, поштење, осећање морала” (PCAHУ). 
до структурног спајања суседних морфема $о$ - и без- и прерасподеле основе, а затим и до појаве проширеног префикса обез- с новим значењем. Јасан доказ формирања проширеног префикса је двокомпонентни ланац присутан у следећој групи глагола.

3.3. У трећој групи глагола можемо препознати процесе двоструке мотивације. Они могу бити мотивисани предлошко-падежном конструкцијом без+именица: о- без- једр-ити „остати без једара”. С друге стране можемо рећи да представљају трећу фазу развоја сегмента обез-, који у овим примерима може да функционише и као потпуна проширена јединица, пошто код њих нема трочланог ланца именица - придев - глагол, већ су изведени од именице и проширеног префикса обез- који има значење „лишити нечег”, а сами глаголи имају значење лишити или остати без онога што значи именица у основи. Сегмент обез- јавља се само у префиксално-суфиксалној творби глагола од именица и не може се додавати већ постојећим глаголима пошто, будући саставним елементом конфикса, он „преводи у класу глагола неглаголне елементе" (в. Исаченко 1960: 150).

витез - обезвитезити нераспр. „оставити (војску) без витезова, лишити витезова”

звоно - обезвонити покр. „оставити без (црквеног) звона, лишити звона”

јарбол - обезјарболити нераспр. „остати без јарбола”

једро - обезједрити нераспр. „остати без једара”

лова - обезловити шатр. „остати без лове, без новца, потрошити новац”

новач - обезновчити покр. „остати без новца, истрошити се”

терет - обестеретити се нераспр. „ослободити терета, растеретити”

брат - обезбратити „остати без браће, изгубити браћу (или једног брата)”

дом - обездомити „оставити без дома, без куће; раскућити”

меденица - обезмеденичити нераспр. „оставити без меденице, звона”

народ - обезнародити заст. „учинити да (земља, град, место и сл.) остане без народа, без људи"

клица - обескличити нераспр. „(нешто) одстранити, уништити заразне клице из или са нечега, стерилисати"

снага - обеснажити „лишити снаге, моћи, довести у стање немоћи, неефикасности, ослабити, исцрпсти"

храброст - обесхрабрити (некога) „учинити да неко изгуби храброст; учинити малодушним, деморалисати"

Глаголи који припадају овој творбеној групи најчешће су ограничене примене и углавном се налазе на периферији књижевног језика. На то нас упућују и квалификатори који у речницима описују њихову употребну вредност. Квалификатор нераспр. (нераспрострањено) указује на уску примену, у неким случајевима могу се сматрати и индивидуализмима. У речницима они су потврђени по једним примером, или представљају неологизме, па нису ни забележени, такође, могу бити део неке специјалне, стручне лексике, нпр. обезмастити уређај, месо и сл., обеспрашити, обезгласити и сл.

Сегмент обез- може се код ове групе глагола јавити у тачно одређеним условима. Не јавља се самостално, већ увек са суфиксом -ити, осим у заста- 
релом глаголу обездевствовати „лишити девичанства”, где чини конфикс са суфиксом -ати. Мотивациона основа ових глагола увек је именица, али опет и ту има изузетака какав чини глагол обесамити се „престати бити сам”, коме је у основи заменица сам.

На основу прегледа стања у српском језику и на основу увида у стање у руском језику, можемо закључити да се процес формирања проширеног префикса обез- одвијао на сличан начин у оба језика, али да има и одређених разлика. Пацјукова (2014: 10) наводи да је у основи формирања проширених афикса појава прерасподеле. На тај начин три структурне врсте морфемског комплекса одговарају трима етапама формирања проширеног афикса. Прва етапа (почетни стадијум) представљена је низањем морфема у творбеном процесу, друга етапа (међустадијум) карактерише се прерасподелом у основи изведене речи, трећа етапа (коначни стадијум) функционисање у језику фонолошки проширеног форманта. Имајући у виду овакав ланац јасно се уочава како се морфемски комплекс обез- појављује, развија и формира као проширена јединица (o-+ без-; о-+без-/ обез-; обез-). Дакле, имамо прву фазу у којој се $о$ - и без- јављају као посебне творбене морфеме у саставу глагола, међуфазу у којој се чувају старе системске везе и развијају нове и трећа фаза у којој се нова јединица самостално употребљава (в. Пацјукова 2014 : 329). Међуфазу карактерише вишеструка мотивација где се као мотивне речи могу јавити придев и именица. Проширени афикс обез- као коначну фазу у развоју карактерише усложена форма и усложено значење. Оно што је важно истаћи је да се у језику проширени афикс може паралелно користити с простим афиксима који улазе у његов састав, дакле, постанак проширеног афикса не доводи до ишчезавања простих (Пацјукова 2014: 333).

4. ЗАкључАк. Творба српских глагола са почетним сегментом обез- може се објаснити на неколико начина.

1. Речници сведоче о постојању глагола на чијем се почетку налази морфема без-. У њиховој мотивационој основи је именица, односно конструкција без + именица (безматичити, беспосличити, бесхлебовати) или могу имати двоструку мотивацију, могу бити изведени од придева или конструкције без + именица (безобразити се, беснажити итд.). Овај творбени тип данас није продуктиван. Већи део ових глагола могао је бити префиксиран префиксом $o$-. На тај начин добили су се свршени глаголи, данас уобичајенији и чешћи у употреби и са развијенијом семантичком структуром (обезглавити, обезматичити се, обезобразити се, обезумити се и сл.). Ипак, са савременог становишта, код наведених, префиксираних глагола можемо уочити промену начина творбе из префиксалног у префиксално-суфиксални и сврстати их у други, следећи творбени тип. 
2. Највећи број глагола са почетним сегментом обез- творбено припада групи глагола у којој се јавља вишеструка мотивација. За ове глаголе карактеристично је постојање творбеног ланца који чине именица, придев и глагол. Именица је обично неизведена (боја, зуб, вода, душа и сл.), придев је изведен од именице префиксом без- (безбојан, безуб, безводан, бездушан и сл.) и на крају је глагол (обезбојити, обезубити, обезводити, обездушти и сл.). Дакле, можемо ове глаголе посматрати као да су изведени од придева (безбојан $\rightarrow o$ безбој-ити) или именице без префикса (боја $\rightarrow$ без-бој-ити). У првом случају препознајемо префиксалну творбу префиксом $o$-, у другом случају у творби учествује проширени префикс обез-. Такође, ови глаголи могу бити мотивисани и предлошко-падежном конструкцијом без+именица.

3. У трећој групи глагола такође уочавамо два модела творбе. Могу настати од предлошко-падежне конструкције без+именица, а други модел је онај у коме проширени префикс обез- функционише самостално. Код ових глагола не постоји потпун ланац именица - придев - глагол, јер недостаје средња карика. Такву творбу срећемо нпр. код глагола обезловити „остати без лове”, обезједрити „остати без једара”, обезвитезити „оставити војску без витезова”, обездевствовати „лишити девичанства” и сл. Овако настао проширени префикс обез- представља резултат усложњавања и форме и значења. Он је наследио значење простих префикса $о$ - и без-, а такође и њихову способност за образовање глагола од именица. Дакле, од префикса o- наслеђено је граматичко значење свршеног вида, а од префикса без- семантика лишавања. Појава проширених афикса не води ишчезавању простих форманата, већ се они користе у језику напоредо с простим афиксима на основу којих су постали (в. Пацјукова 2014: 37). Систем префикса у српском језику формиран је још у периоду општесловенског језичког јединства, веома је стабилан и појава нових, проширених префикса није честа. Ипак, стална потреба за именовањем појава из реалног света води ка формирању нових творбених средстава. Иако је у том случају чешће позајмљивање, могуће је и да се од већ постојећих српских морфема формирају нове творбене морфеме - проширени афикси. На тај начин језик се богати новим морфемама, новим лексемама и творбеним моделима. 


\section{ЛИТЕРАТУРА}

Бабић 2002: S. Babić, Tvorba riječi u hrvatskome književnome jeziku. Treće, poboljšano izdanje. Zagreb: Nakladni zavod Globus - Hrvatska akademija znanosti i umjetnosti.

Белић 1949: А. Белић, Савремени српскохрватски књижевни језик II: Наука о грађењу речи, Београд: Научна књига.

Гаговић 2004: С. Гаговић, Из лексике Пиве (село Безује), Српски дијалектолошки зборник, LI, 1-312.

Драгићевић 2013: Р. Драгићевић, Глаголи са два префикса у српском с освртом на стање у другим словенским језицима, Зборник Матице српске за славистику, 83, 257-268.

Ђукановић 1995: П. Ђукановић, Говор Драгачева, Српски дијалектолошки зборник, XLI, 1-240.

Исаченко 1960: А. В. Исаченко, Грамматический строй русского языка 6 сопоставлении с словаиким, Братислава: Издательство словацкой академии наук.

Јовановић 2020: В. Јовановић, Именице и придеви са префиксима без- и неу савременим текстовима српског православног богословља, Црквене студије XVII, Ниш (рад у штампи).

Клајн 2002: И. Клајн, Творба речи у савременом српском језику. Део 1, Слагање и префиксащија, Београд: Завод за уџбенике и наставна средства, Институт за српски језик САНУ - Нови Сад: Матица српска.

Маретић 1931: T. Maretić, Gramatika i stilistika hrvatskoga ili srpskoga književnog jezika, Zagreb: Matica hrvatska.

Маројевић 2005: Р. Маројевић, Творба речи у савременом српском језику Ивана Клајна (1), Српски језик, X/1-2, 658-779.

Пацјукова 2009: О. А. Пацюкова, Протяжённый префикс обез-(обес-): формирование и функцонирование, Вестник Нижегородского университета им. Н. И. Лобачевского 6-2, Нижний Новогород, 308-313.

Пацјукова 2011: О. А. Пацюкова, Термин и понятие „морфемный комплекс”, Вестник Нижегородского университета им. Н. И. Лобачевского Нижний Новогорд, 6-2, 496-499.

Пацјукова 2012: О. А. Пацюкова, Формирование сложных аффиксов и проблема челнимоссти основ, Известия Пензенского государственного педагогическкого университета им. В. Г. Белинского, 27, Пенза, 352-356. 
Пацјукова 2014а: О. А. Пацюкова, Переразложение и закономерности развития протажённых аффиксов в русском языке, автореферат, Нижний Новогород.

Пацјукова 2014б: О. А. Пацюкова, Переразложение и закономерности развития протажённых аффиксов в русском языке, Диссертация на соискание ученой степени доктора филологических наук, Нижний Новогород.

РГ 1980: Русская грамматика, I, гл. ред. Н. Ю. Шведова, Москва: Наука.

РЈАЗУ: Рјечник хрватскога или српскога језика. Загреб: Југославенска академија знаности и умјетности.

Ројзензон 1966: Л. И. Ройзензон, О многоприставочных глаголах русского яазыка, Русский язык в школе, Москва, 87-95.

РСАНУ: Речник српскохрватског књижевног и народног језика, XVI, Београд: Српска академија наука и уметности - Институт за српски језик.

Стијовић 2014: Р. Стијовић, Речник Васојевића, Београд: Чигоја штампа.

Ћихоњска 1987: M. Cichońska, Префиксално-суфиксални деноминативни глаголи у савременом српскохрватском књижевном језику, Научни састанак слависта у Вукове дане, 16/1, 75-81.

Ћупић Д. и Ж. 1997: Д. Ћупић и Ж. Ћупић, Речник говора Загарача, Српски дијалектолошки зборник, XLIV.

XГ 1997: E. Barić, M. Zinka, V. Zečević, M. Lončarić, D. Malić, S. Pavešić, M. Peti, Hrvatska gramatika, Zagreb: Školska knjiga.

Штасни 2013: Г. Штасни, Речи о човеку (Номинација човека у српском језику), Нови Сад: Филозофски факултет.

\section{VERBS WITH THE INITIAL MORPHEME SEGMENT OBEZ- IN THE SERBIAN LANGUAGE}

$$
\text { Summary }
$$

A word formation and morfeme analysis of verbs with the initial morpheme segment obez- showed that they can be derived in several ways. Historically, there are verbs with the morpheme obez- at the begining and can also be prefixed with the prefix o-. From a modern point of view, these prefixed verbs have changed their word formation type from prefixation to a prefix-suffix type, appointing them to the following word formation type we will describe. The largest number of verbs are characterized by multiple motivation - thay 
can be derived of adjectives with the prefix o- (безбојан $\rightarrow$ о-безбој-ити), or derived from

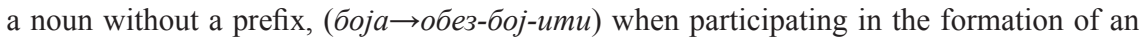
extended prefix obez-. Also, these verbs can be motivated by a prepositional case construcion bez+noun. Acharacteristic of these verbs is the existence of a complete chain: noun - adjective - verb (boja - bezbojan - obezbojiti). In the third group of verbs we can also recognise two models of formation. The first one is a prepositional case construcion obez + noun, and the second model is the one where the extended prefix obez-operates independently. These verbs don't show the complete noun - adjective - verb chain type, because they lack the middle link. We can see such a formation for verb types like obezjedriti ,to lose ones nucleus”, obezviteziti „to leave the military without knights” etc. This kind of an extended prefix is the result of a complex binding of forms and meanings. It has inherited the meaning of the simple prefixes o- and bez-, but also their capacity for constructing verbs from nouns. 